\title{
Glycated haemoglobin and glycated protein and glucose concentrations in necropsy blood samples
}

\author{
W G JOHN, ${ }^{*}$ K W M SCOTT, $†$ D M HAWCROFT $\ddagger$
}

From the ${ }^{*}$ Department of Clinical Chemistry, New Cross Hospital, Wolverhampton, the $†$ Department of Pathology, The Royal Hospital, Wolverhampton, and the $\ddagger$ School of Pharmacy, Leicester Polytechnic, Leicester

SUMMARY Glycated haemoglobin and glycated protein (fructosamine) and blood glucose concentrations were measured in blood samples collected from 75 patients at necropsy. Estimation of blood glucose was a poor indicator of glycaemia before death. Measurement of glycated haemoglobin by affinity chromatography distinguished non-diabetic patients from diabetic patients. The distinction was not as clear cut when $\mathrm{HbA}_{1}$ was estimated using electroendosmosis. Seven patients, who at necropsy had no known history of diabetes, had glycated haemoglobin concentrations in the diabetic range. Two of these patients were found to be diabetic, and diabetes had been suspected at some time in another three patients.

It is concluded that measurement of glycated haemoglobin or $\mathbf{H b A}_{1}$, in necropsy specimens is a valuable tool for assessing glycaemic control in known diabetic patients, and may be useful in diagnosing previously unsuspected diabetes.

Biochemical examination of necropsy material may be of value for determing the metabolic abnormalities responsible for death: results may establish a cause of death when necropsy fails to show clinically important anatomical disease, or may help evaluate the physiological effects of recognisable anatomic lesions. Hill suggested that blood glucose estimation after death was of no value.' He showed that blood glucose concentrations decreased by about $0.7 \mathrm{mmol} / \mathrm{hour}$ after death due to continued cell metabolism and bacterial degradation. Based on these findings a normal blood glucose concentration in life would be expected to have fallen to concentrations approaching zero in specimens collected six to 10 hours after death. In contrast, Tonge and Wannan showed that true glucose was detectable up to 60 hours after death. ${ }^{2}$

Glycated haemoglobin provides an assessment of long term carbohydrate control in diabetic patients. ${ }^{3}$ Interest in this began with the observation by Rahbar in 1968 that diabetic patients had raised concentrations of "fast-moving" haemoblobin $\left(\mathrm{HbA}_{1}\right)$ when analysed by electrophoresis. ${ }^{4}$ Subsequent work in several laboratories led to the identification of $\mathbf{H b A}_{\mathrm{lc}}$ as glycated haemoglobin ${ }^{5-6}$ with the Amadori product of glucose binding preferentially to the $\mathrm{N}$-amino terminal valine of the $\beta$-chain. Glycation at other sites on the haemoglobin molecule does not result in an electrophoretically distinct fraction.

The methods available for the estimation of glycated haemoglobin either measure total $\mathrm{HbA}_{1}$ (electroendosmosis) ${ }^{7}$ or the main stable glycated fraction $\mathrm{HbA}_{\mathrm{Ic}}$ after isolation from the other fractions (isoelectric focusing). ${ }^{8}$ More recently methods using affinity chromatography separation have been described.' This separates haemoglobins to which is bound a glucose molecule and therefore measures total glycated haemoglobin.

Several workers have investigated the possibility of using glycated haemoglobin as an indicator of glucose intolerance with methods based on charge separation. ${ }^{10-12}$ They reported poor sensitivity with only patients with pronounced glucose intolerance showing high results. Workers using affinity chromatography have recently described more favourable sensitivity. ${ }^{13-14}$

In this study we used affinity chromatography and electroendosmosis to estimate total glycated haemoglobin and $\mathbf{H b A}_{1}$ (respectively) in samples collected from 75 cadavers coming to necropsy. Glycated protein was estimated as fructosamine. The results were then compared with the known clinical state of the patients before death.

\section{Patients and methods}

A series of unselected patients who came to necropsy over one year were included in the study. Of the 75 patients studied, 42 were men (seven known diabetics) 

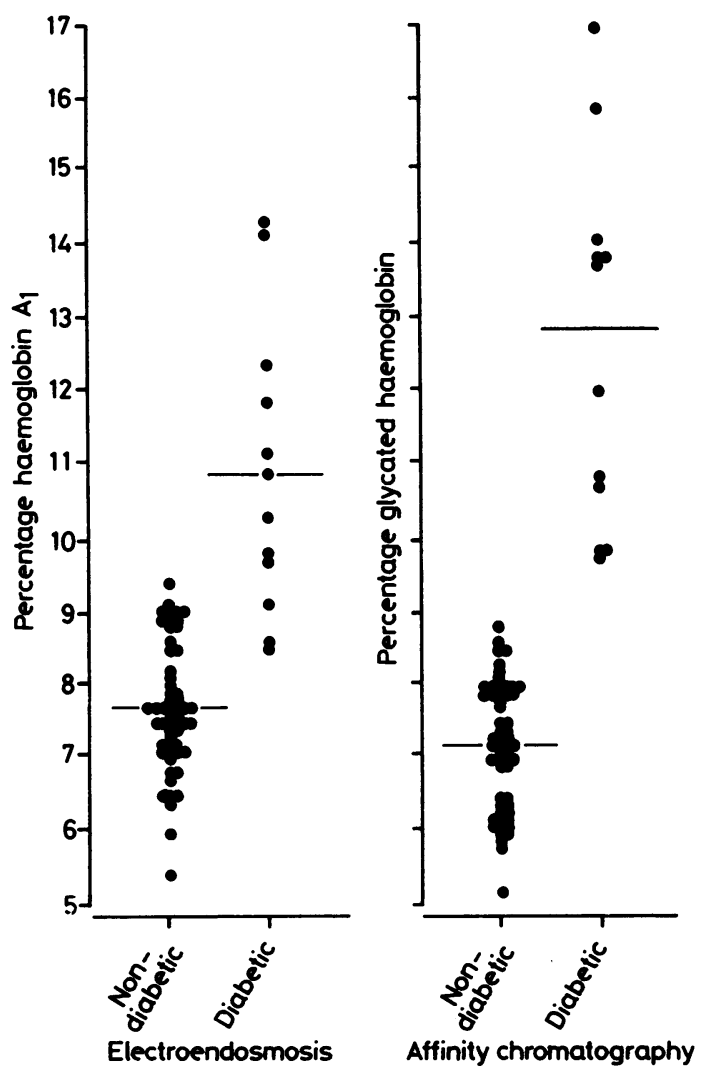

Figure Glycated haemoglobin (measured by affinity chromatography) and $\mathrm{HbA}_{1}$ (measured by electroendosmosis) found in necropsy blood samples of known diabetics and patients with no previous history of diabetes.

and 33 women (five known diabetics). The mean time from death to necropsy was $51 \cdot 3$ (range 12-144) hours, 16.5 (range four to 36 ) hours of which were at room temperature and 40.0 (range five to 120 ) at $4^{\circ} \mathrm{C}$. The mean age of the non-diabetic patients was 69.2 (range 23-90) years. The mean age in the diabetic group was $69 \cdot 2$ (range 61-82) years.

Blood was collected at necropsy from the femoral vein and added to tubes containing fluoride oxalate as an anticoagulant. Twenty patients also had blood collected from the right side of the heart: five also had blood collected from the opposite femoral vein and from axillary veins. Three patients had blood samples collected from the right and left femoral veins, the aorta, the superior vena cava, the right ventricle, the inferior vena cava and the hepatic vein.

Blood glucose concentration was measured the day of collection using a glucose oxidase/4-aminophenazone method on a YSI analyser. Glycated haemoglobin was estimated by affinity chromatography as previously described ${ }^{9}$ and $\mathbf{H b A}_{1}$ was estimated using the Corning Glytrac electroendosmosis procedure (Corning Medical and Scientific). The latter two measurements were performed within five days of collection, the haemolysates being stored at $4^{\circ} \mathrm{C}$. Estimation of fructosamine value was performed by a modification of the method described by Johnson et $a l^{15}$ on a Technicon RA 1000 . Specimens were stored at $-20^{\circ} \mathrm{C}$ for up to one month before estimation.

\section{Results}

\section{BLOOD GLUCOSE}

In all but one case the glucose concentration in the blood taken from the femoral vein was decreased -in most cases to less than $2.0 \mathrm{mmol} / \mathrm{l}$. One diabetic patient showed a high glucose concentration of 22.8 $\mathrm{mmol} / \mathrm{l}$. Twenty patients with no history of diabetes also had glucose estimated on blood collected from the right side of the heart. The mean blood glucose concentration in these specimens was 15.7 (range 0.2 $33.2) \mathrm{mmol} / \mathrm{l}$ and was significantly higher $(\mathrm{p}<0.001)$ than the mean blood glucose concentration of 1.7 (range 0-6.4) $\mathrm{mmol} / \mathrm{l}$ found in the femoral veins of these patients. The increased blood glucose concentration in the right side of the heart was not related to the length of time after death. Three of these patients had further blood samples collected, and the mean blood glucose concentrations in these specimens were: 0 (right femoral vein), $\mathbf{0 \cdot 2}$ (left femoral vein), $\mathbf{0}$ (aorta), 17.5 (superior vena cava), 16.7 (right ventricle), 28.5 (inferior vena cava) and 48.2 (hepatic vein) $\mathrm{mmol} / \mathrm{l}$.

GLYCATED HAEMOGLOBIN AND HAEMOGLOBIN A, Glycated haemoglobin and $\mathrm{HbA}_{1}$ were estimated on specimens collected from the right and left femoral veins, the right and left axillary veins, and the right side of the heart of five patients. In all patients the variation in the glycated haemoglobin results was within the precision of the method. In one, the variation of $\mathrm{HbA}$ results was greater than the precision of the method.

The mean glycated haemoglobin and $\mathrm{HbA}_{1}$ values in the patients with no known history of diabetes were found to be $7.7 \%$ (range $5 \cdot 2-15 \cdot 2 \%$ ) and $8.0 \%$ (range $5 \cdot 3-12 \cdot 3 \%$ ), respectively. The diabetic patients showed a mean glycated haemoglobin result of $12.8 \%$ (range $9 \cdot 9-17 \cdot 2 \%$ ) and a mean $\mathrm{HbA}_{1}$ of $10.9 \%$ (range $8 \cdot 5-14 \cdot 4 \%)$. Using Smirnov's test, ${ }^{16}$ the glycated haemoglobin and $\mathrm{HbA}_{1}$ results found in the diabetic population were significantly different from those in the non-diabetic population (at the $95 \%$ confidence level).

Seven patients, who at necropsy had no known history of diabetes, produced results that in life would be regarded as abnormal. ${ }^{914}$ The medical histories of these seven patients were further investigated. The results (table) show that two of the seven were probably diabetic and another had had the blood glucose artificially raised with a dextrose infusion. These cases were excluded from the non-diabetic 
Table Percentage of patients showing increased glycated haemoglobin at necropsy

\begin{tabular}{|c|c|c|c|c|}
\hline$H b A_{1}$ & $\begin{array}{l}\text { Glycated } \\
\text { haemoglobin }\end{array}$ & $\begin{array}{l}\text { Known clinical } \\
\text { state }\end{array}$ & $\begin{array}{l}\text { Necropsy } \\
\text { findings }\end{array}$ & $\begin{array}{l}\text { Subsequent } \\
\text { information }\end{array}$ \\
\hline $10 \cdot 2$ & $10 \cdot 0$ & & $\begin{array}{l}\text { Ischaemic heart } \\
\text { disease }\end{array}$ & $\begin{array}{l}6 \text { years ago glucose } \\
6 \mathrm{mmol} / \mathrm{l}\end{array}$ \\
\hline $9 \cdot 0$ & $10 \cdot 0$ & $\begin{array}{l}\text { Strokes, amputation, } \\
\text { renal and cardiac } \\
\text { failure }\end{array}$ & $\begin{array}{l}\text { Ischaemic heart } \\
\text { disease }\end{array}$ & $\begin{array}{l}\text { No mention of } \\
\text { diabetes mellitus }\end{array}$ \\
\hline $10 \cdot 9$ & $13 \cdot 0$ & & $\begin{array}{l}\text { Ischaemic heart } \\
\text { disease }\end{array}$ & $\begin{array}{l}\text { BM glucose } \\
\text { stick } 9 \mathrm{mmol} / 1\end{array}$ \\
\hline $10 \cdot 0$ & $11 \cdot 4$ & $\begin{array}{l}\text { Rheumatoid ischaemic } \\
\text { heart disease, } \\
\text { fracture of femur }\end{array}$ & $\begin{array}{l}\text { Cholecystitis, } \\
\text { ischaemic heart disease } \\
\text { rheumatoid arthritis }\end{array}$ & $\begin{array}{l}\text { Numerous blood } \\
\text { glucose estimations } \\
\text { of } 7-7.5 \mathrm{mmol} / \mathrm{l}\end{array}$ \\
\hline $12 \cdot 3$ & $15 \cdot 2$ & Depression & $\begin{array}{l}\text { Suicide by } \\
\text { electrocution }\end{array}$ & $\begin{array}{l}\text { Normal OGTT } \\
7 \text { years ago }\end{array}$ \\
\hline $10 \cdot 0$ & $10 \cdot 2$ & $\begin{array}{l}\text { Sudden death, } \\
\text { profound hypoglycaemia }\end{array}$ & $\begin{array}{l}\text { Infarcted bowel, } \\
\text { pulmonary emboli, } \\
\text { ? nodule in pancreas }\end{array}$ & $\begin{array}{l}\text { On dextrose for } \\
\text { two days before } \\
\text { death; (glucose } \\
25 \mathrm{mmol} / \mathrm{l} \text { ) }\end{array}$ \\
\hline $10 \cdot 7$ & $12 \cdot 5$ & $\begin{array}{l}\text { Haematemesis, abdominal } \\
\text { pain }\end{array}$ & $\begin{array}{l}\text { Perforated duodenal } \\
\text { ulcer }\end{array}$ & $\begin{array}{l}\text { Glucose } 10.9 \mathrm{mmol} / 1 \\
\text { before death }\end{array}$ \\
\hline
\end{tabular}

group. The other four patients had no recorded history of diabetes. Using Healy's method for the removal of outliers, the range of results ( $95 \%$ confidence limits) in the non-diabetic group was $5 \cdot 9-8 \cdot 6 \%$ for glycated haemoglobin and 6.4-9.4\% for $\mathrm{HbA}_{1}$. With the exception of these seven patients, the distribution of results for both groups is shown in the figure.

\section{FRUCTOSAMINE}

Most blood specimens were haemolysed when collected and were therefore considered to be unsuitable for analysis. Other specimens had very little plasma associated with the red cells. Most samples had a high total protein content, with a mean concentration of 78.8 (range 44-120) $\mathrm{g} / \mathrm{l}$. The albumin concentration was low with a mean result of 19.2 (range $\langle 5-39$ ) g/l, resulting in a protein : albumin ratio of $3 \cdot 8$. The mean fructosamine value measured in 26 non-diabetics was 1.06 (range 0.33-1.84) $\mathrm{mmol} / \mathrm{l}$, which, when corrected for protein concentration, gave a mean of 14.3 (range $3 \cdot 2-26) \mu \mathrm{mol} / \mathrm{g}$ protein. The mean fructosamine value in three diabetics was $2.09(1.73,1.83$ and 2.70$)$ $\mathrm{mmol} / \mathrm{l}$, which, when corrected for protein concentration, was $31 \cdot 1(25 \cdot 1,40 \cdot 7$ and $27 \cdot 6) \mu \mathrm{mol} / \mathrm{g}$ protein.

\section{Discussion}

Despite the introduction of insulin in the treatment of diabetes over 60 years ago, diabetes continues to devastate the health of a considerable proportion of people around the world. It is the seventh leading cause of death in the United States, accounting for about 150000 deaths annually. ${ }^{17}$ In the United Kingdom diabetes is reported to be the primary cause in $0.7 \%$ of male and $0.95 \%$ of female deaths. Diabetes as a secondary cause may be a contributory factor in many more deaths, with the suspected incidence of diabetes being between $2 \%$ and $4 \%$ in the general population.
Attempted assessment of glycaemic state before death is normally based on the estimation of glucose in blood samples collected at necropsy. In this study we have shown that glucose concentrations in necropsy peripheral blood samples were significantly decreased when compared with non-fasted blood glucose concentrations in a healthy population $(3.6-7 \cdot 0 \mathrm{mmol} / \mathrm{l})$. Similar results have been reported by other workers. ${ }^{1}$ The high glucose concentrations in blood collected from the right side of the heart have also been reported, ${ }^{1}$ although the finding seems to be largely ignored by pathologists. The high blood glucose concentration in the right heart is probably due to glycogen breakdown occurring in the liver; this would account for the finding that the highest glucose concentrations are found in blood samples collected in the hepatic vein. Due to the large variation in blood glucose concentrations no normal range for necropsy could be established.

Unlike glucose, in most cases glycated haemoglobin and $\mathrm{HbA}_{1}$ concentrations did not differ in blood samples collected from various sites in the body. The range (after removal of outliers) of glycated haemoglobin found in the patients with no known history of diabetes was similar to that previously reported in a healthy population $(5 \cdot 0-8 \cdot 5 \%),{ }^{9}$ but the slight increase may be due to this population being older than that previously investigated. The range of $\mathrm{HbA}_{1}$ in this group was higher than that reported by Menard et $a l^{7}$ in a healthy population. This may be due to necropsy adducts (other than glucose) adding to haemoglobin and thereby affecting its charge characteristic. This would affect the electroendosmosis method but not the affinity method. In the diabetic patients the glycated haemoglobin results tended to be higher than those for $\mathrm{HbA}_{1}$, confirming previously reported findings that in the diabetic ranges affinity chromatography produces higher results. ${ }^{9}$

The distinct results found in the diabetic and non- 
diabetic groups using affinity chromatography were similar to those reported in life by investigators who compared glycated haemoglobin results (measured by affinity chromatography) with those of an oral glucose tolerance test (OGTT), although in this study we did not consider the group with impaired glucose tolerance. There was an overlap in the $\mathbf{H b A}_{1}$ results obtained in both groups, with three diabetic patients displaying results in the non-diabetic range. Other workers who used electroendosmosis to estimate $\mathrm{HbA}_{1}$ and compared the results with the outcome of an OGTT reported poor sensitivity for $\mathrm{HbA}_{1}$ in diagnosing diabetes. The difference in the diagnostic sensitivity of the two methods may be due to the better precision of the affinity method, or that electroendosmosis may be affected by several factors that do not interfere with the affinity method. When glycated haemoglobin was used to assess glycaemic control in the known diabetics, three patients showed good, three moderate, and six poor controls.

Seven patients, who at necropsy had no known history of diabetes, displayed results (glycated haemoglobin or $\mathrm{HbA}_{1}$, or both) that in life would be regarded as abnormal. All seven patients displayed an increased glycated haemoglobin result; $\mathrm{HbA}_{\text {r }}$ was raised in only six patients. The case histories of these seven patients were further investigated. It was found that before death three had been suspected at some time of being diabetic, although diabetes was not confirmed. Two patients had had a glucose estimate that in itself was diagnostic of diabetes.

Assessment of fructosamine value is a recently described method for estimating glycated protein, which is reported to reflect glycaemic control over the preceding one to three weeks. The estimate is performed on serum or plasma. Unfortunately, specimens collected at necropsy tend to be haemolysed or very haemoconcentrated, or both, and are therefore unsuitable for analysis. Fructosamine estimation was only possible in 26 non-diabetic and three diabetic patients. None of the seven non-diabetic patients who displayed an increased glycated haemoglobin estimation had a fructosamine estimate. There was reasonably clear distinction between the diabetic and nondiabetic groups, especially after the results were corrected for protein content. Interpretation of the fructosamine results was difficult in these patients as the protein content (albumin : protein ratio) differed considerably from that found in life.

We conclude that measurement of glycated haemoglobin or $\mathrm{HbA}_{1}$ in specimens collected at necropsy provides a valuable tool for assessing glycaemic control of known diabetic patients just before death, and may be useful for the diagnosis at necropsy of previously unsuspected diabetes. Estimation of blood glucose concentration is of no value in assessing glycaemic control at necropsy, although pathologists should be aware of the differences found at various sites in the body.

We are grateful to Nordisk (UK) Ltd for providing financial support during this study.

\section{References}

1 Hill E. Significance of dextrose and nondextrose reducing substances in post-mortem blood. Archives of Pathology 1941;32:452-73.

2 Tonge JI, Warran JS. The post-mortem blood sugar. Med J Aust 1949;1:439-47.

3 Jovanovic L, Peterson CM. The clinical utility of glycosylated haemoglobin. Am J Med 1981;70:331-8.

4 Rahbar S. An abnormal haemoglobin in red cells of diabetics. Clin Chim Acta 1968;22:296-8.

5 Bookchin RM, Gallop RM. Structure of haemoglobin $A_{1 c}$; Nature of the N-terminal b chain blocking group. Biochem Biophys Res Commun 1968;32:86-93.

6 Koeing RJ, Blobstein H, Carami A. The structure of haemoglobin $A_{1 c}, J$ Biol Chem 1972;252:2992-7.

7 Menard L, Dempsey ME, Blankstein LA, et al. Quantitative determination of glycosylated haemoglobin $A_{1}$ by agar gel electrophoresis. Clin Chem 1980;26:1598-602.

8 Stickland MH, Perkins CM, Wales JK. The measurement of haemoglobin ${ }_{A l c}$ by isoelectric focussing in diabetic patients. Diabetologia 1982;22:315-7.

9 John WG, Albutt EC, Handly G, Richardson RW. Affinity chromatography method for the measurement of glycosylated haemoglobin: comparison with two methods in routine use. Clin Chim Acta 1984;136:257-62.

10 Boucher BJ, Welch SG, Beer MS. Glycosylated haemoglobin in the diagnosis of diabetes mellitus and for the assessment of chronic hyperglycaemia. Diabetologia 1981;21:34-6.

11 Albutt EC, Nattrass M, Northam BE. Glucose tolerance and glycosylated haemoglobin measurement for the diagnosis of diabetes mellitus, an assessment of the criteria of the WHO Expert Committee on Diabetes Mellitus 1980. Ann Clin Biochem 1985;22:67-73.

12 Lester E, Frazer AD, Shepherd CA, Woodroffe FJ. Glycosylated haemoglobins as an alternative to the glucose tolerance test for the diagnosis of diabetes mellitus. Ann Clin Biochem 1985;22:74-8.

13 Hall PM, Cook JGH, Sheldon J, Rutherford SM, Gould BJ. Glycosylated haemoglobin and glycosylated plasma proteins in the diagnosis of diabetes mellitus and impaired glucose tolerance. Diabetes Care 1984;7:147-50.

14 John WG, Richardson RW. Glycosylated haemoglobin levels in patients referred for oral glucose tolerance tests. Diabetic Med 1986;3:46-8.

15 Johnson RN, Metcalf PA, Baker JR. Fructosamine: a new approach to the estimation of serum glycosylprotein. An index of diabetic control. Clin Chim Acta 1982;127:87-95.

16 Conover WJ. Practical nonparametric statistics. New York: John Wiley and Sons, 1971:309.

17 National Diabetes Data Group. Diabetes in America. Diabetes data compiled 1984. Bethesda, Maryland. National Institute of Arthritis, Diabetes, Digestive and Kidney Disease, National Institute of Health, 1985.

Requests for reprints to: Dr W G John, Department of Clinical Chemistry, New Cross Hospital, Wolverhampton WV10 0QP, England. 